\title{
AN EPIDEMIC OF INFLUENZA. RESULTS OF PROPHYLACTIC INOCULATION OF A COMPLEX INFLUENZA A-DISTEMPER VACCINE ${ }^{1}$
}

\author{
By JOHN W. BROWN, MONROE D. EATON, GORDON MEIKLEJOHN, \\ JOHN B. LAGEN, AND W. J. KERR \\ (From the Department of Medicine, University of California Medical School, San Francisco, \\ and the Research Laboratory ${ }^{2}$ of the California State Department \\ of Public Health, Berkeley)
}

(Received for publication June 24, 1941)

Investigations in recent years have demonstrated that clinical influenza may be caused by at least two serologically specific filtrable viruses ( 1 to 6 ). It is probable that other etiologic agents will be discovered. The clinical characteristics of influenza caused by different agents are exceedingly uniform and no accurate method of distinguishing them by clinical means has been found ( 6 to 10 ). The etiologic diagnosis of influenza must at present rest upon discovery of the virus responsible in the throat washings from ill patients or upon detection of a rise of specific antibodies in the blood during convalescence. Antibody studies by means of complement fixation or neutralization tests have been found reliable in indicating infection with the known viruses $(11,13,14)$. On the basis of etiology, a classification of influenza has been suggested $(11,12)$. Influenza $A$ will indicate the disease caused by the virus isolated by Smith, Andrewes and Laidlaw in 1933, subsequently termed human influenza virus, epidemic influenza virus and now influenza virus A. Since 1933 many strains of this virus have been found in association with widespread outbreaks of influenza in many parts of the world which have occurred at intervals of about two years (6 to 11). In 1940, Francis $(3,6)$ and Magill $(4,5)$ isolated a virus which was antigenically dissimilar from virus $A$ and proved it to be the cause of outbreaks of influenza in the United States in that year. Influenza $B$ indicates the disease caused by this virus. Francis has shown that the epidemic of 1936 in California and elsewhere in the United States was

1 This study was aided by a grant from the Christine Breon Fund for Medical Research, University of California Medical School.

2 Operated with the support and under the auspices of the International Health Division of the Rockefeller Foundation. influenza B. The cases of clinical influenza for which no etiology can be established by appropriate tests are designated influenza X. Several undiscovered virus agents may be included in this group.

The knowledge that influenza comprises a group of clinically similar diseases caused by several serologically distinct viruses is of epidemiological significance, especially when the problem of prevention by vaccination is considered. It seems important to study carefully epidemics of influenza in the hope of developing means of early differentiation of types and of establishing the cause of each epidemic either by isolation of the virus or serological tests. We present observations made during an epidemic of influenza $A$ which occurred in San Francisco in November and December 1940 and January 1941. The clinical features of the disease and the results of prophylactic inoculation against influenza A are described. The results were controlled by antibody studies on many individuals.

\section{METHOD}

Blood specimens were taken during the acute stage and again two to three weeks later from 70 patients with clinical influenza who were admitted to the University of California Hospital. Complement fixation tests against influenza A were done on all specimens and neutralization tests on most of them. Neutralization tests with influenza $B$ were made on the serums of all patients whose specimens failed to reveal a rise in antibodies to influenza $A$. The methods used have been described in detail elsewhere $(13,14,18)$. One thousand minimal lethal doses were used in the neutralization tests. These tests were performed in the Research Laboratory of the California State Department of Public Health. The appearance of antibodies to influenza $\mathrm{A}$ was considered demonstrated if complement fixation or neutralization titers, or both, showed a definite increase between acute and convalescent specimens. Patients whose blood showed this increase are referred to as positive for influenza $A$ and it is assumed that they had influenza A. The majority showed 
a four-fold or greater increase in titer by either or by both tests. Four patients had a two-fold rise by complement fixation test and one of these had a two-fold rise by neutralization test. These patients are included in the group positive for influenza A. A complete analysis of the antibody studies is reserved for a separate report (15).

The inoculation experiments were carried out with the complex vaccine of Horsfall and Lennette which was supplied through the courtesy of Dr. F. L. Horsfall, Jr. of the International Health Division of the Rockefeller Foundation $(16,17,18)$. It was prepared from chick embryos inoculated with influenza $A$ and canine distemper viruses (18). The dessicated material was rehydrated by adding $55 \mathrm{cc}$. of sterile distilled water to $25 \mathrm{cc}$. of dried vaccine immediately before inoculation. Inoculations were made by injecting $1 \mathrm{cc}$. of the resulting suspension subcutaneously. A single injection was employed in every instance.

\section{EPIDEMIOLOGY}

The group studied consists of the population of the University of California Medical Center in San Francisco. It includes medical, dental, pharmacy and nursing students, members of the nursing and house physician staffs, technicians and secretaries of the teaching departments, and members of the various maintenance services. It represents nearly all persons who spend full time at the Medical Center and consists of a total of 1213 individuals.

Influenza A appeared in the Hawaiian Islands on September 15, 1940, and reached epidemic proportions on about October 10, 1940.8 In November, a little over a month after its appearance in Hawaii, cases of the same disease occurred in San Francisco. The first patient was admitted to the University of California Hospital on November 23. From this date to January 4, 1941, 271 individuals of the Medical Center population of 1213, or 22 per cent, had a febrile disease of one or more days' duration. This incidence was ascertained by canvass of the various departments. The interpretation of this figure is complicated by the difficulties usually encountered in a survey by canvass and by the interference of prophylactic measures. Incidence is considered in more detail in the section on vaccination.

Eighty of the 271 patients were admitted to the University of California Hospital. These included 29 nurses and nursing students, 17 medical students, 12 physician staff members, 14 dental students, 5 pharmacy students and 3 secretaries and hygienists. Of these, 70 were studied for antibodies to influenza $A$. Those negative to type $\mathbf{A}$ virus were studied for antibodies to influenza $B$. Fifty-three, or $\mathbf{7 5}$ per cent, were positive for influenza $A$. None was positive for influenza B. The first case of influenza A occurred on November 23, 1940, and the last on January 4, 1941. The peak incidence occurred in the week of November 29 to December 6. Table I shows the spread of the epidemic as indicated by dates of onset of those patients on whom antibody studies were done.

${ }^{3}$ This epidemic was studied by one of us (M. D. E.).
TABLE I

Dates of onset by weeks of influenza in patients on whom antibody studies were done

\begin{tabular}{|c|c|c|c|c|}
\hline \multirow[b]{2}{*}{ Weeks } & \multicolumn{2}{|c|}{$\begin{array}{l}\text { Total number } \\
\text { of patients }\end{array}$} & \multicolumn{2}{|c|}{$\begin{array}{l}\text { Inoculated } \\
\text { patients }\end{array}$} \\
\hline & $\begin{array}{l}\text { Posi- } \\
\text { tive } \\
\text { for } \\
\text { influ- } \\
\text { enza } \\
\text { A }\end{array}$ & $\begin{array}{l}\text { Nega- } \\
\text { tive } \\
\text { for } \\
\text { influ- } \\
\text { enza A } \\
\text { and B }\end{array}$ & $\begin{array}{l}\text { Posi- } \\
\text { tive } \\
\text { for } \\
\text { influ- } \\
\text { enza } \\
\mathbf{A}\end{array}$ & $\begin{array}{l}\text { Nega- } \\
\text { tive } \\
\text { for } \\
\text { influ- } \\
\text { enza A } \\
\text { and B }\end{array}$ \\
\hline $\begin{array}{l}\text { November } 23 \text { to } 29,1940 \ldots \ldots \ldots \\
\text { November } 30 \text { to } 2 \text { December } 6 \ldots \ldots \\
\text { December } 7 \text { to } 13 \ldots \ldots \ldots \ldots \ldots \ldots \\
\text { December } 14 \text { to } 20 \ldots \ldots \ldots \ldots \ldots \\
\text { December } 21 \text { to } 27 \ldots \ldots \ldots \ldots \\
\text { December } 28 \text { to January } 4,1941 \ldots\end{array}$ & $\begin{array}{r}13 \\
23 \\
7 \\
8 \\
1 \\
1\end{array}$ & $\begin{array}{l}2 \\
2 \\
5 \\
3 \\
3 \\
2\end{array}$ & $\begin{array}{l}0 \\
72 \text { to } 8 \\
2^{11,12} \\
1^{23} \\
0 \\
1^{20}\end{array}$ & $\begin{array}{l}0 \\
10 \\
3^{9} \text { to } 12 \\
2^{10,23} \\
2^{29,21} \\
1^{23}\end{array}$ \\
\hline 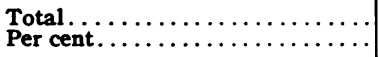 & $\begin{array}{l}53 \\
75\end{array}$ & $\begin{array}{l}17 \\
25\end{array}$ & 11 & 9 \\
\hline
\end{tabular}

Superscripts indicate number of days after inoculation when onset of influenza occurred.

\section{RESULTS OF INOCULATION WITH VACCINE}

A total of 273 individuals of the Medical Center population was inoculated with the complex vaccine of Horsfall and Lennette. The injections were made on November 26 and 28 and December 3. The epidemic was in progress a few days before the first inoculations were carried out.

No significant reactions occurred following injection. Tenderness over the injected site, which persisted three to four days without redness or swelling, was a common experience. A few individuals had slight redness and swelling of the arm for twenty-four hours. One individual had generalized urticaria three days after injection and another had mild urticaria seven days afterwards. One experienced an erythematous eruption with swelling of hands, feet, and lips on the fifth day. Another suffered from rhinitis and sneezing for twelve hours beginning one hour after inoculation. None of these individuals had a history of allergic disease.

The incidence of influenza in vaccinated and control groups was compared (Table II). A febrile disease resembling influenza occurred in 235 of the 940 control subjects, an incidence of 25 per cent as ascertained by history. Thirty-six cases developed among 273 inoculated persons, an incidence of 13 per cent. The hospital staff group consisting of nurses, house physicians and medical laboratory personnel, was constantly under observation so that the information obtained about this smaller group is reliable. It consisted of 334 in- 
TABLE II

Clinical influenra. Incidence and results of prophylactic inoculation

\begin{tabular}{|c|c|c|c|c|c|c|c|}
\hline \multirow[b]{2}{*}{ Groups } & \multirow[b]{2}{*}{ Total } & \multicolumn{3}{|c|}{ Not inoculated } & \multicolumn{3}{|c|}{ Inoculated } \\
\hline & & 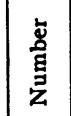 & 胥 & 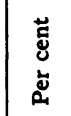 & 䓌 & 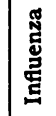 & 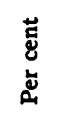 \\
\hline $\begin{array}{l}\text { Service group }{ }^{*} \ldots \ldots \\
\text { Student group } \dagger \ldots . . . \\
\text { Hospital staff group } \ddagger \\
\text { Total population. . . }\end{array}$ & $\begin{array}{r}416 \\
463 \\
334 \\
1213\end{array}$ & $\begin{array}{l}383 \\
368 \\
189 \\
940\end{array}$ & $\begin{array}{r}113 \\
40 \\
82 \\
235\end{array}$ & $\begin{array}{l}29.5 \\
10.8 \\
43.4 \\
25.0\end{array}$ & $\begin{array}{r}33 \\
95 \\
145 \\
273\end{array}$ & $\begin{array}{r}6 \\
9 \\
21 \\
36\end{array}$ & $\begin{array}{r}18.1 \\
9.4 \\
14.5 \\
13.0\end{array}$ \\
\hline
\end{tabular}

* Includes members of service units, such as secretaries, technicians, librarians; and maintenance units, such as janitors.

† Includes medical, dental and pharmacy students.

‡ Includes nursing students and staff, house physicians and staffs of medical laboratories.

dividuals. Of 189 controls, 82 , or 43 per cent, developed the disease. The incidence of influenza shown in Table II was much higher in the hospital control group than in the general control group, either because of better observation or because of greater exposure. The unvaccinated student group could be observed only if the individual members reported illness to the student infirmary. The Christmas holiday began during the decline in incidence of cases of influenza and the students left the institution during this period. Consequently, the incidence presented for the student group is inaccurate. The only figures in the survey subject to a significant error are those relative to the incidence among the general campus population, especially in the student group, who were not inoculated; all inoculated persons and the hospital staff group were observed. The general incidence of influenza at the Medical Center must have been higher than 25 per cent. Therefore, the difference in incidence between vaccinated and control groups is probably greater than that presented for the total population and may be more accurately represented by the experience of the hospital staff group.

Antibody studies were made on acute and convalescent blood specimens from patients of both groups. Fifty control and 20 vaccinated subjects who had influenza were studied. Forty-two ( 84 per cent) of the controls and 11 (55 per cent) of those inoculated showed significant rises in antibodies to influenza $A$ and were considered positive for influenza A (Table III). This further reduces the incidence of influenza $A$ in the vaccinated group as compared to the controls.

Since influenza A appeared before vaccination was carried out, the days of onset must be compared in order to evaluate the effect of vaccination. Only established cases of influenza A will be considered. Table I shows the general incidence by weeks and indicates both control and vaccinated subjects. The number of days after inoculation when influenza A occurred in vaccinated persons are demonstrated in Table I by superscripts.

Of those inoculated who subsequently had influenza, only 4 were shown to have acquired influenza A more than ten days after inoculation. In 2 of these the disease developed twenty-three and thirty-nine days, respectively, and each devel-

TABLE III

Results of antibody studies on control and inoculated cases of clinical influenza

\begin{tabular}{c|c|c|c}
\hline \hline Group & $\begin{array}{c}\text { Number of } \\
\text { patients } \\
\text { studied }\end{array}$ & $\begin{array}{c}\text { Positive for } \\
\text { influenza A }\end{array}$ & $\begin{array}{c}\text { Per cent } \\
\text { positive }\end{array}$ \\
\hline Control...................... & 50 & 42 & 84 \\
Inoculated.... & 20 & 11 & 55 \\
Total........ & 70 & 53 & 75 \\
\hline
\end{tabular}

oped significant increases in titer of both complement fixing and neutralizing antibodies during the disease. These 2 cases show clearly that vaccination did not afford certain protection. Table I shows that the incidence of influenza $A$ in the epidemic reached its peak during the ten days after vaccination and then rapidly subsided in the population as a whole during the time when vaccination might be expected to become effective. It is unfortunate that the experiment was not begun sooner. However, the difference in incidence of influenza $\mathrm{A}$ in the vaccinated as compared to the control group is striking and may be due to a protective effect of vaccination which began sooner after inoculation than is usually considered likely.

\section{CLINICAL FEATURES}

The clinical characteristics described are based on the observation of patients in the hospital who were subsequently shown to have suffered from either influenza $A$, or neither influenza $A$ nor $B$, as established by antibody studies. As indicated be- 
fore, this group consisted of 70 persons, 53 of whom had influenza $\mathrm{A}$ and 17 neither influenza $\mathrm{A}$ nor B. Of these, 20 had been previously vaccinated and the characteristics of influenza $\mathrm{A}$ in them are also considered. Table IV summarizes the incidence of various symptoms. Table $\mathrm{V}$ in-

TABLE IV

Frequency of symptoms in patients with influenza of known and unknown etiology

\begin{tabular}{|c|c|c|c|c|c|c|}
\hline \multirow[b]{2}{*}{ Symptoms } & \multicolumn{4}{|c|}{ Influenza $\mathrm{A}$} & \multicolumn{2}{|c|}{$\begin{array}{c}\text { Neither } \\
\text { influenza } \\
\text { A nor B }\end{array}$} \\
\hline & $\begin{array}{l}\text { Con- } \\
\text { trols }\end{array}$ & $\begin{array}{l}\text { Vacci- } \\
\text { nated }\end{array}$ & Total & $\begin{array}{c}\text { Per } \\
\text { cent }\end{array}$ & $\begin{array}{l}\text { Vacci- } \\
\text { nated } \\
\text { and } \\
\text { con- } \\
\text { trols }\end{array}$ & $\begin{array}{l}\text { Per } \\
\text { cent }\end{array}$ \\
\hline 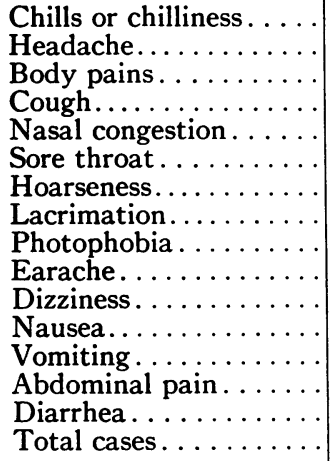 & \begin{tabular}{r|}
26 \\
29 \\
37 \\
31 \\
17 \\
18 \\
3 \\
4 \\
3 \\
3 \\
1 \\
5 \\
4 \\
3 \\
0 \\
42
\end{tabular} & $\begin{array}{r}3 \\
8 \\
9 \\
8 \\
4 \\
7 \\
2 \\
2 \\
1 \\
0 \\
0 \\
1 \\
1 \\
0 \\
2 \\
11\end{array}$ & $\begin{array}{r}29 \\
37 \\
46 \\
39 \\
21 \\
25 \\
5 \\
6 \\
4 \\
3 \\
1 \\
6 \\
5 \\
3 \\
2 \\
53\end{array}$ & \begin{tabular}{|r}
56.6 \\
69.8 \\
86.7 \\
73.5 \\
39.6 \\
47.1 \\
9.4 \\
11.3 \\
7.5 \\
5.6 \\
1.8 \\
11.3 \\
9.4 \\
5.6 \\
3.7
\end{tabular} & $\begin{array}{r}6 \\
14 \\
16 \\
5 \\
5 \\
8 \\
2 \\
2 \\
0 \\
0 \\
0 \\
5 \\
4 \\
2 \\
2 \\
17\end{array}$ & $\begin{array}{c}35.2 \\
82.3 \\
94.1 \\
29.4 \\
29.4 \\
47.0 \\
11.7 \\
11.7 \\
0 \\
0 \\
0 \\
29.4 \\
23.5 \\
11.7 \\
11.7\end{array}$ \\
\hline
\end{tabular}

dicates the duration of fever, maximum temperature and maximum leukocyte counts, respectively, in the three groups. Influenza $\mathrm{A}$ in this epidemic was explosive in onset and severe during the height of the fever. Convalescence was rapid in most cases. A comparison of the symptoms experienced by patients with influenza $A$ and by those with influenza of unknown etiology fails to reveal a significant difference (Table IV). Cough was more often present in patients with influenza A. In both groups general symptoms and symptoms of upper respiratory tract inflammation were predominant. In no case was the nasal congestion mentioned in the table suggestive of coryza. Sore throat was usually accompanied by a prominence of lymphoid follicles on the pharyngeal wall but not by a diffuse inflammation. Earache, when it occurred, was due to myringitis rather than to otitis media.

The duration of fever did not differ significantly in the two types of influenza (Table V). Ninety per cent of the patients with influenza $A$ had a febrile period of two to five days, and 68.5 per cent had a febrile period of three to four days. Those with influenza of unknown etiology suffered fever for from one to five days in 93.6 per cent and for three to four days in 50 per cent. The table indicates that patients with influenza $\mathrm{A}$ had significantly higher maximum temperatures

TABLE V

Duration of fever, maximum temperature and maximum leukocyte count in patients with influenza of known and unknown etiology

\begin{tabular}{|c|c|c|c|c|c|c|}
\hline & \multicolumn{4}{|c|}{ Influenza $\mathrm{A}$} & \multicolumn{2}{|c|}{$\begin{array}{c}\text { Neither } \\
\text { influenza } \\
\text { A nor B }\end{array}$} \\
\hline & $\begin{array}{l}\text { Con- } \\
\text { trols }\end{array}$ & $\begin{array}{l}\text { Vacci- } \\
\text { nated }\end{array}$ & Total & $\begin{array}{l}\text { Per } \\
\text { cent }\end{array}$ & $\begin{array}{l}\text { Vacci- } \\
\text { nated } \\
\text { and } \\
\text { con- } \\
\text { trols }\end{array}$ & $\begin{array}{c}\text { Per } \\
\text { cent }\end{array}$ \\
\hline \multicolumn{7}{|c|}{ DURATION OF FEVER } \\
\hline days & & & & & & \\
\hline 1 & 0 & 0 & 0 & 0 & 1 & 6.2 \\
\hline 2 & 1 & 0 & 1 & 1.9 & 3 & 18.7 \\
\hline 3 & 11 & 3 & 14 & 27.4 & 4 & 25.0 \\
\hline 4 & 17 & 4 & 21 & 41.1 & 4 & 25.0 \\
\hline 5 & 8 & 2 & 10 & 19.6 & 3 & 18.7 \\
\hline 6 & 1 & 0 & 1 & 1.9 & 1 & 6.2 \\
\hline 7 & 2 & 0 & 2 & 3.9 & 0 & 0 \\
\hline 9 & 0 & $1^{*}$ & $1^{*}$ & 1.9 & 0 & 0 \\
\hline 12 & $1 \dagger$ & 0 & $1 \dagger$ & 1.9 & 0 & 0 \\
\hline Total cases & 41 & 10 & 51 & & 16 & \\
\hline
\end{tabular}

MAXIMUM TEMPERATURE

\begin{tabular}{l|r|r|r|r|r|r}
\hline degrees Centigrade & & & & & & \\
$37.0-37.5$ & - & 1 & 1 & 1.9 & 4 & 26.6 \\
$37.5-38.0$ & 3 & - & 3 & 5.8 & 6 & 40.0 \\
$38.0-38.5$ & 12 & - & 12 & 23.5 & 1 & 6.6 \\
$38.5-39.0$ & 20 & 7 & 27 & 52.9 & 2 & 13.3 \\
$39.0-39.5$ & 5 & 2 & 7 & 13.7 & 1 & 6.6 \\
$39.5-40.0$ & 1 & - & 1 & 1.9 & 1 & 6.6 \\
\hline Total cases & 41 & 10 & 51 & & 15 & \\
\hline
\end{tabular}

MAXIMUM LEUKOCYTE COUNT

\begin{tabular}{c|r|r|r|r|r|r}
\hline $\begin{array}{c}\text { thousands per } \\
\text { cubic millimeter } \\
0-5\end{array}$ & & & & & & \\
$5-7$ & 15 & 2 & 11 & 22.6 & 4 & 33.3 \\
$7-10$ & 10 & 1 & 11 & 22.6 & 1 & 8.3 \\
$10-15$ & 3 & 2 & 5 & 10.2 & 1 & 8.3 \\
$15-20$ & $1 \dagger$ & $1^{*}$ & 2 & 4.0 & 2 & 16.6 \\
\hline Total cases & 38 & 11 & 49 & & 12 &
\end{tabular}

* Complicated by pneumococcus Type IV lobar pneumonia.

† Complicated by atypical pneumonia. 
than those with influenza of unknown etiology. The maximum leukocyte counts as tabulated show little difference between the groups. Maximum counts were below 7,000 per cubic millimeter in 63.4 per cent and below 10,000 per cubic millimeter in 86 per cent of the cases of influenza A. Pulmonary complications occurred in 2 patients, both of whom were shown to have had influenza A. Pneumococcus Type IV lobar pneumonia developed in a 20-year-old student nurse after four days of fever with clinical and serological evidence of influenza A beginning December 19. Blood culture was negative. The patient recovered during sulfathiazole therapy. She had been inoculated with vaccine twenty-three days prior to onset of influenza A. At the onset of pneumonia, her leukocyte count increased from 5,600 to 20,000 per cubic millimeter. The second patient was a $27-$ year-old dental student who had evidence of atypical pneumonia in both lung bases on the fourth day of fever in the course of influenza $A$ which had begun on December 6. He experienced a total febrile period of twelve days. The leukocyte count rose from 6,100 to 11,000 per cubic millimeter on the seventh day, to 16,470 per cubic millimeter on the tenth day. No causative organism was discovered in sputum or blood and no effect on the course was observed during the exhibition of sulfathiazole. It is probable that this patient had atypical pneumonia of virus etiology, possibly due to the virus of influenza $\mathrm{A}$. He also made an uneventful recovery. He had not been inoculated with vaccine.

The characteristics of influenza A observed during this epidemic were similar to those in epidemics previously described $(7,8,25)$. The disease was of moderate severity, the incidence of pulmonary complications was low, and no deaths occurred. We did not find it possible to distinguish clinically between influenza $\mathrm{A}$ and influenza of unknown etiology which occurred during the same epidemic. There was no evidence that the disease was modified in persons who had previously received a prophylactic inoculation. Subclinical infection may have influenced the results of antibody studies. This was not determined.

\section{DISCUSSION}

Since influenza of known etiology has been divided into two types, $\mathrm{A}$ and $\mathrm{B}$, each caused by a different virus agent, much of the confusion concerning the epidemiology of the group of diseases called influenza has been dispelled. That all cases of influenza are not caused by known agents seems clear. Influenza $X$ may represent a variety of agents of virus or possibly other nature. In the group reported, a high proportion of cases were influenza A. Nevertheless, a definite proportion of cases appeared simultaneously on which tests failed to reveal evidence of infection with either virus A or B. An analysis of these cases failed to reveal an accurate clinical method of differentiation. All were clinical influenza, appearing and disappearing at the same time. Therefore, influenza $A$ and a febrile respiratory disease of unknown etiology occurred together in this epidemic. Influenza B was not discovered.

Since the discovery of the virus etiology of one form of influenza (1), studies on the effectiveness of vaccination with active and inactive virus have been made in animals and humans (19 to 30). The parenteral inoculations of both active and inactive material by either single or multiple injections have been made by the intraperitoneal, intramuscular, subcutaneous and intradermal routes. In ferrets, mice and humans, rises in antibodies have been induced by vaccination. In ferrets and mice relative immunity has developed to subsequent infection which is to a great extent strainspecific and which persists three to four months $(16,17,19,22,27)$. Several experiments have been carried out in which human volunteers were inoculated subcutaneously or intramuscularly with active or inactive virus suspensions and subsequently observed during an epidemic of influenza A ( 23 to 25,28 to 30$)$. None of these experiments has resulted in conclusive proof of the effectiveness of vaccination of human beings against influenza A. In all of them evaluation has been made difficult by various factors, such as a low attack rate in controls, too early appearance of the epidemic after vaccination, small number of subjects involved, or paucity of tests on throat washings or blood specimens. In two studies $(24,25)$, virus was obtained from patients who had been previously vaccinated. Recent inoculation experiments with the complex vaccine of Horsfall and Lennette have given some evidence that a protective effect against influenza $A$ was obtained 
(30). In another study in California during the recent epidemic of influenza $A$, the formalininactivated complex vaccine and a living vaccine of influenza A virus appeared to give comparable results. The results were suggestive of a protective effect against influenza $A$ after inoculation with either preparation at one institution but were questionable at another (29).

The observations we present are also difficult to evaluate and do not give conclusive evidence of protection against influenza $A$ by vaccination. This was due to the presence of cases of influenza $\mathrm{A}$ in the community before inoculations were begun and to the fact that the peak incidence was reached within ten days after inoculation of most individuals. Furthermore, two vaccinated individuals acquired influenza $A$ twenty-three and thirty-nine days, respectively, after inoculation. However, the incidence of influenza in vaccinated individuals was markedly less than in the controls. In addition, the disease which occurred in vaccinated persons was proved to be influenza $\mathrm{A}$ by antibody studies in a much smaller percentage of those inoculated than among the control. group. The definite difference in incidence of disease between inoculated persons and controls is difficult to explain unless we assume that some protection was afforded by the vaccine. If this occurred, the vaccine must have produced an immunity earlier after inoculation than is usually considered possible and at a time when measurable protective antibodies are absent or just beginning to rise in the blood. The factors of age, nutrition and previous exposure to influenza A may be of significance in determining the speed with which antibody formation occurs and protection develops. These factors may also explain differences in results of vaccination of different groups with the same vaccine. The other alternative in the present study is to consider that the inoculated group escaped infection by chance, which is, however, statistically unlikely.

\section{SUMMARY}

1. Clinical and epidemiological observations made during an epidemic of influenza $\mathrm{A}$ are presented.

2. Antibody studies indicated that influenza $A$ was the causative agent in 75 per cent of the cases.
There was no evidence of the presence of influenza B.

3. Subcutaneous inoculation of 273 of a total of 1213 individuals was performed with a mixed influenza $\mathrm{A}-$ distemper vaccine. A marked reduction in incidence of influenza A occurred in the vaccinated group as compared to the controls. The incidence of influenza in the control groups was between 25 and 43 per cent as compared to 13 to 15 per cent in those inoculated. These observations suggest that a measure of protection was afforded by vaccination but do not permit the conclusion that efficient protection resulted.

We wish to thank Dr. Saxton T. Pope, Jr., and Dr. Elizabeth Davis of the Student Health Service, and the heads of departments and individual members of the University of California Medical Center for their cooperation. We appreciate the technical assistance rendered by Mrs. Evelyn Neufeld, Mr. C. R. Nicewonger and Miss Ruth Verwey.

\section{BIBLIOGRAPHY}

1. Smith, W., Andrewes, C. H., and Laidlaw, P. P., A virus obtained from influenza patients. Lancet, 1933, 2, 66.

2. Francis, T., Jr., Differentiation of influenza $A$ and influenza $B$ by the complement-fixation reaction. Proc. Soc. Exper. Biol. and Med., 1940, 45, 861.

3. Francis, T., Jr., A new type of virus from epidemic influenza. Science, 1940, 92, 405.

4. Magill, T. P., A virus from cases of influenza-like upper respiratory infection. Proc. Soc. Exper. Biol. and Med., 1940, 45, 162.

5. Magill, T. P., Repeated attacks of influenza. Proc. Soc. Exper. Biol. and Med., 1941, 46, 316.

6. Francis, T., Jr., The problem of epidemic influenza. Trans. and Studies. Coll. Phys. Phila., 1941, 8, 218.

7. Stuart-Harris, C. H., Smith, W., and Andrewes, C. $H$., The influenza epidemic of January-March, 1939. Lancet, 1940, 1, 205.

8. Horsfall, F. L., Jr., Hahn, R. G., and Rickard, E. R., Four recent influenza epidemics; an experimental study. J. Clin. Invest., 1940, 19, 379.

9. Taylor, R. M., Petrilla, A., and Dreguss, M., Certain broad epidemiological aspects of influenza. J. Infect. Dis., 1941, 68, 90.

10. Taylor, R. M., and Dreguss, M., Influenza virus studies during the 1939 epidemic in Central Europe. J. Infect. Dis., 1941, 68, 79.

11. Rickard, E. R., Lennette, E. H., and Horsfall, F. L., Jr., A comprehensive study of influenza in a rural community. U. S. Publ. Health Rep., 1940, 55, 2146.

12. Horsfall, F. L., Jr., and others, The nomenclature of influenza. Lancet, 1940, 2, 413. 
13. Horsfall, F. L., Jr., Neutralization of epidemic influenza virus. The linear relationship between the quantity of serum and the quantity of virus neutralized. J. Exper. Med., 1939, 70, 209.

14. Eaton, M. D., and Rickard, E. R., Application of the complement-fixation test to the study of epidemic influenza. Am. J. Hyg., 1941, 33 (Sect. B), 23.

15. Eaton, M. D. (To be published.)

16. Horsfall, F. L., Jr., and Lennette, E. H., A complex vaccine effective against different strains of influenza virus. Science, 1940, 91, 492.

17. Horsfall, F. L., Jr., and Lennette, E. H., The synergism of human influenza and canine distemper viruses in ferrets. J. Exper. Med., 1940, 72, 247.

18. Horsfall, F. L., Jr., Lennette, E. H., and Rickard, E. R., A complex vaccine against influenza $A$ virus; quantitative analysis of the antibody response produced in man. J. Exper. Med., 1941, 73, 335.

19. Smith, W., Andrewes, C. H., and Laidlaw, P. P., Influenza: Experiments on the immunization of ferrets and mice. Brit. J. Exper. Path., 1935, 16, 291.

20. Francis, T., Jr., and Magill, T. P., Vaccination of human subjects with virus of human influenza. Proc. Soc. Exper. Biol. and Med., 1936, 33, 604.

21. Francis, T., Jr., and Magill, T. P., The antibody response of human subjects vaccinated with the virus of human influenza. J. Exper. Med., 1937, 65, 251.

22. Andrewes, C. H., and Smith, W., Influenza: Further experiments on the active immunization of mice. Brit. J. Exper. Path., 1937, 18, 43.

23. Stokes, J., Jr., and others, Results of immunization by means of active virus of human influenza. J. Clin. Invest., 1937, 16, 237.

24. Stokes, J., Jr., and others, Vaccination against epidemic influenza with active virus of human influenza. Am. J. Med. Sc., 1937, 194, 757.

25. Stuart-Harris, C. H., Andrewes, C. H., and Smith, W., A study of epidemic influenza with special reference to the 1936-1937 epidemic. Med. Res. Council, Special Report Ser. 228, 1938.

26. Morrison, A. P., and others, Complement-fixation studies on the sera of individuals vaccinated with active virus of human influenza. Am. J. Med. Sc., 1939, 197, 253.

27. Francis, T., Jr., Quantitative relationships between the immunizing dose of epidemic influenza virus and the resultant immunity. J. Exper. Med., 1939, 69, 283.

28. Taylor, R. M., and Dreguss, M., An experiment in immunization against influenza with a formaldehydeinactivated virus. Am. J. Hyg., 1940, 31 (Sect. B), 31 .

29. Martin, W. P., and Eaton, M. D., Experiments on the immunization of human beings against influenza A. Proc. Soc. Exper. Biol. and Med., 1941, 47, 405.

30. Horsfall, F. L., Jr., Lennette, E. H., Rickard, E. R., and Hirst, G. K., Studies on the efficacy of a complex vaccine against influenza A. Pub. Health Rep., 1941, 56, 1863. 